\title{
Environmental management of peri-urban natural resources: L'Horta de Valencia case study
}

\author{
J. L. Miralles i Garcia \\ Department of Urban Planning, Polytechnic University of Valencia, \\ Spain
}

\begin{abstract}
L'Horta de Valencia is a peri-urban agricultural space with recognized values as a heritage: historic, cultural, agricultural, economic, landscape and natural resource. Across Europe, there are only six similar landscapes according to the DOBRIS report of the European Environment Agency (1998). Many studies and authors show their values. This historical zone has been irrigated, since the Medieval Age, by seven channels of Túria's river, and irrigation water is managed by specific organization of seven irrigation communities, one for each channel, with a historical Court of Waters. UNESCO named the Court of Waters as a World Heritage. The surface of the irrigation zones historically was very extensive with about 23,000 ha. Today there are about 12,000 ha. There have been several attempts to plan and protect this area and landscape, but so far, none has succeeded. The last attempt was in about 2006 by the Territorial Action Plan to Protect Horta of Valencia, finalized in 2010 but not approved. Meanwhile, the urbanization of agricultural areas has continued. In fact, this situation occurs as a result of management problems. Protection of anthropic spaces requires maintenance of existing economic activities, particularly, but not only, agricultural activities. Stakeholders expect more income from urbanization processes. Therefore, the main problem to execute any plan with success is the management of agricultural space to maintain economic activities associated with the agricultural landscape. This paper analyzes the behavior of stakeholders and structural causes that explain the failure of Horta planning and propose management systems to generate objective conditions in order to maintain this exceptional landscape.

Keywords: territorial management, agricultural heritage, peri-urban zones, regional planning.
\end{abstract}




\section{Introduction}

Valencia's Horta has a very special landscape. It is a very fertile land around Valencia City. This area is irrigated by a system of seven canals that distribute water - Túria River (Quart, Benàger i Faitanar, Tormos, Mislata, Mestalla, Favara, Rascanya i Rovella). The origin of the city is Roman. The origin of the canals may be Arabian but we do not know this for certain.

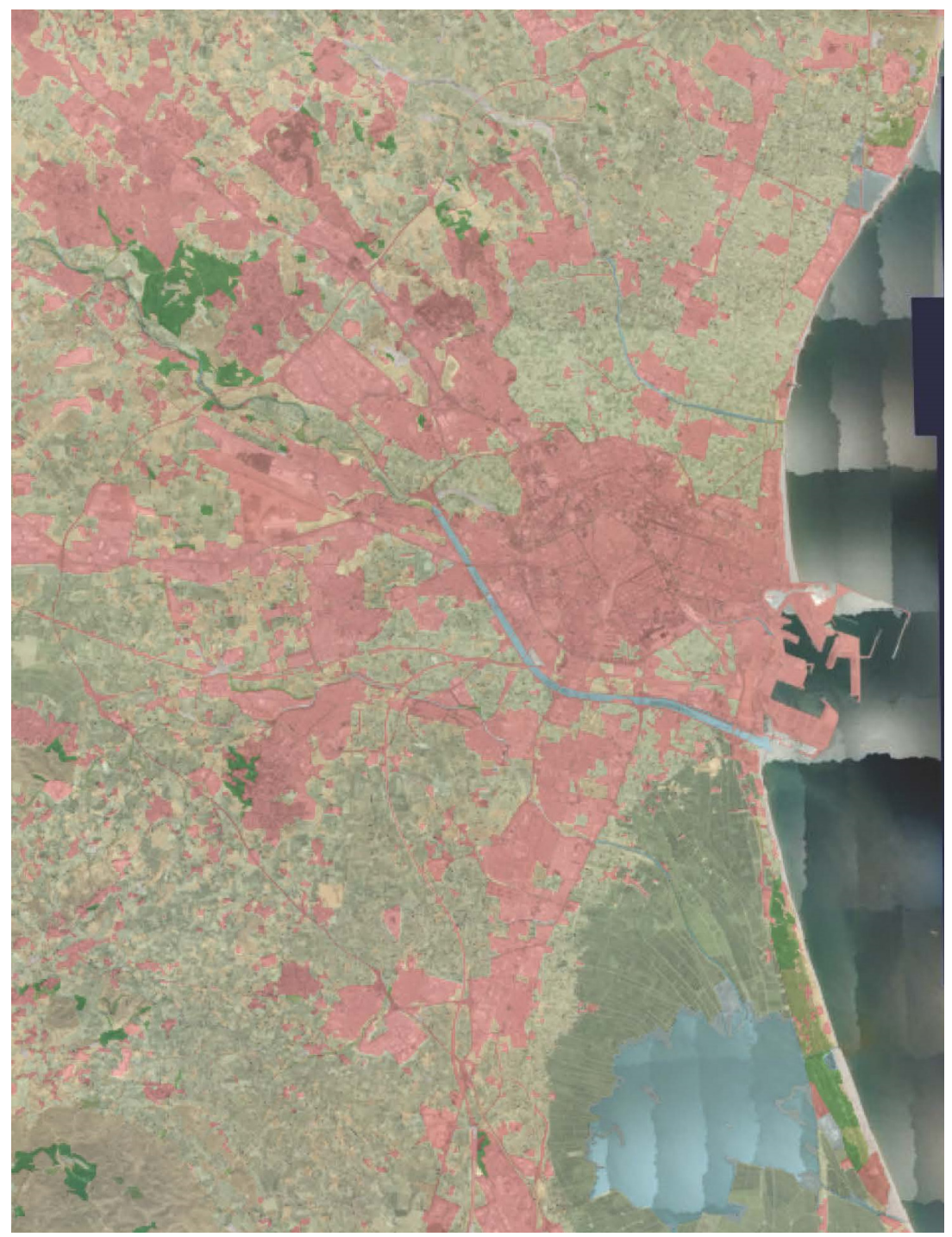

Figure 1: Metropolitan area of Valencia with urban areas in red. Origin: ICV, SIOSE, 2011[1]. 
From the Medieval Age, the irrigation problems between farmers has been argued in the Water Court (Tribunal de las Aguas). Even today, the Water Court dispenses justice every Thursday at the door of the Apostles of Cathedral. All processes are exclusively oral and judgments are enforced by the verbal agreement of farmers who submit to the court. In 2009, the Water Court of Valencia was declared World Heritage by UNESCO as an intangible heritage.

The historical area of fertile land or irrigated land was very extensive, about 10,000 ha [2]. Today, more than half of this area had been transformed into urban land. Besides this historic agricultural area, there exists another irrigation area, since the XIX century, with a surface area of about 10,000 ha. These agricultural soils are of exceptional quality and are very lacking. The Valencian Community, with about $23,000 \mathrm{~km}^{2}$ of surface area, in 1998 have only $3.9 \%$ of this surface area with similarly agricultural quality. As a reference, in 2006, the surface of urban areas in Valencian Community was 4.86\% [4].

Note that the climate in Valencia is Mediterranean: hot and dry. Irrigation water in Valencia comes from two sources: the Túria River, the only river that exists in this area, and especially groundwater. With these conditions, the earth gives 3 or 4 crops a year.

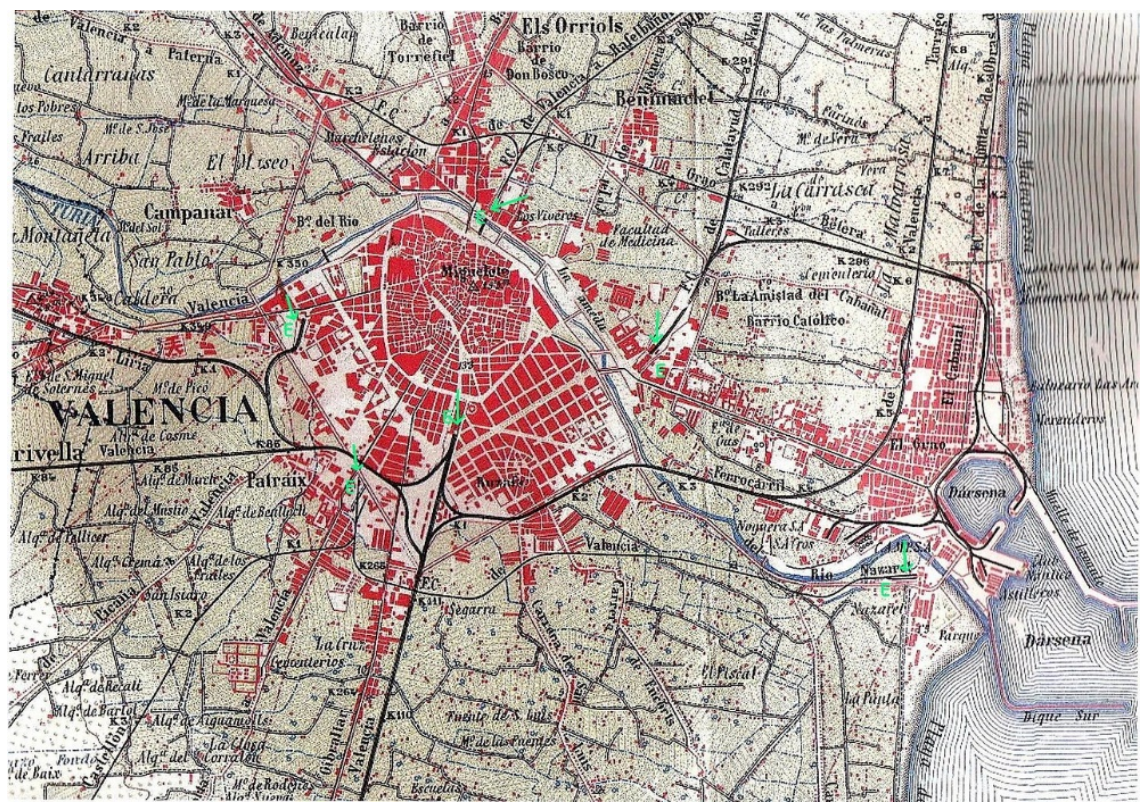

Figure 2: Detail of Valencia and surrounding area in 1944. Origin: Historical National Topographic Map of Spain, 1:50,000 original scale.

The farmers of this area have a specific cultural heritage created by historical experience. The special landscape of L'Horta de València has special values as a cultural heritage, historical heritage, anthropic landscape, architectural heritage and hydraulic world heritage and, of course, for its agricultural activity [5]. 
In 1995, the European Environmental Agency published a report [6] about European landscapes which identified only 6 places in Europe with this type of landscape, two of them in Spain - Valencia and Murcia.

From 1978, when democracy was implanted in Spain, there have been many attempts to plan and manage this peri-urban area, but to date, all have failed. Therefore, gradually, this space has become a benchmark for the effectiveness or failure of environmental policies.

\section{Objectives}

Many authors have studied this space from different viewpoints. This paper analyzes the structural causes that explain why, today, despite the social and scientific recognition of values of this space and the very extensive legal framework for environmental protection, it has not been possible to plan and manage use in this special space.

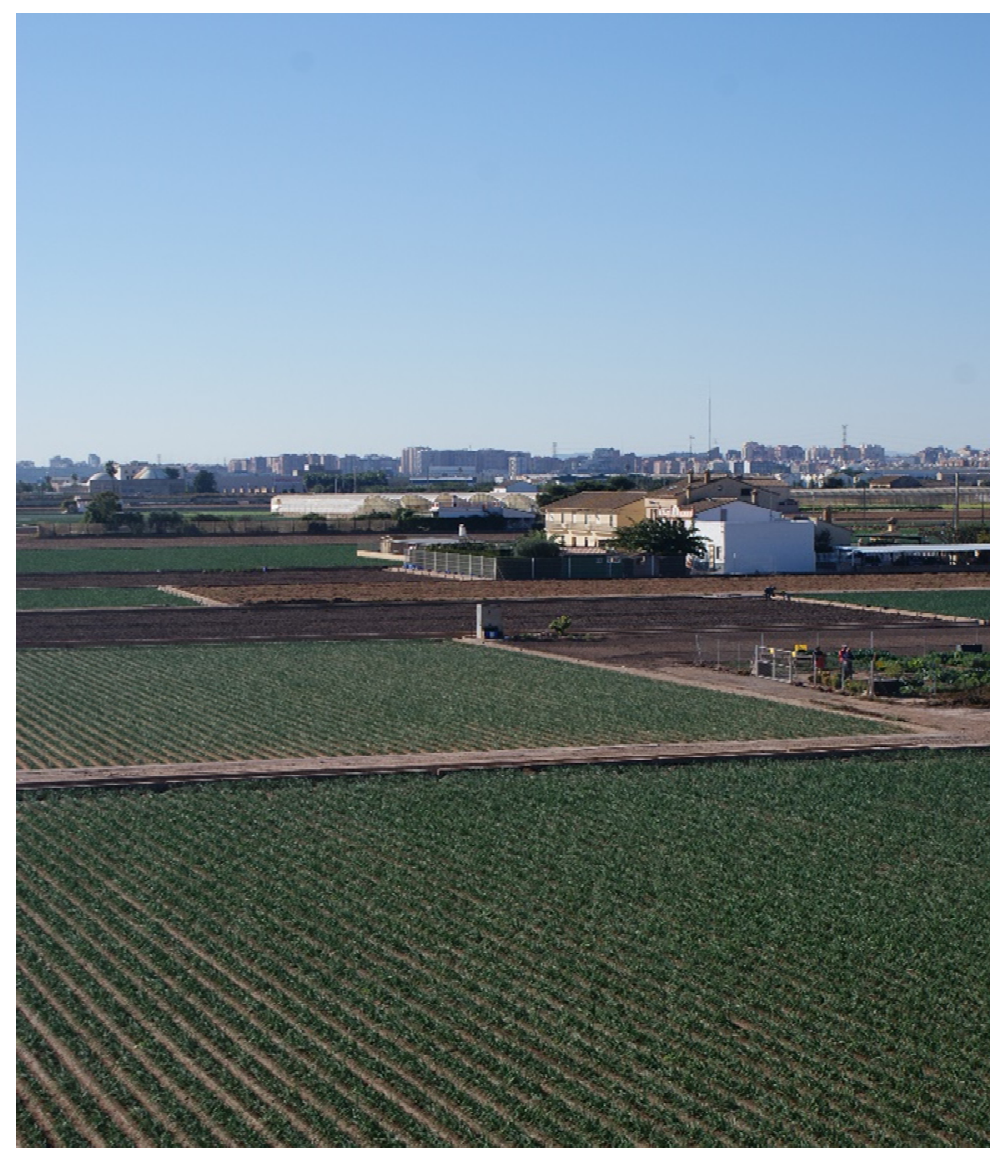

Figure 3: Image of irrigated land of L'Horta de Valencia. 


\section{Historical attempts to planning and management of peri-urban Valencia's Horta}

In 1946 the first metropolitan plan of Valencia, Plan General de Ordenación Urbana de Valencia y su Cintura, was approved. In 1957 a major flood occurred. The Spanish government decided to change the route of the Túria River via the south of Valencia (South Solution) and build a new channel through which to divert water in case of new floods. For this reason, the metropolitan plan was revised and a new plan was approved in 1966, Plan General de Valencia y su comarca adaptado a la solución Sur (General Urban Plan of Valencia and the surrounding area adapted to South Solution).

The first plan was oriented to conserve agriculture, to produce food in autarchy scenario (from the end of the Civil War in 1939 to the beginning of the open economy in 1959).

The second plan was elaborated to the situation of a real estate boom (period 1959-1972) and very intense changes in economy. The agricultural sector was becoming less important. During this time, the environment is not considered important and all historical heritage or natural resources can be destroyed, if necessary, to allow for the increase in income and economic progress. The metropolitan plan of 1966 had urban expansion and infrastructure promotion around the city as objectives.

Finally, in the 1970s, a popular movement for conserving natural spaces or natural resources around Valencia such as L'Albufera Lake, Saler beach or L'Horta historical agricultural land was born in Valencia. At that time, the government promoted a project of tourist city in the coastal zone of El Saler, near to Albufera Lake. The objective of this project was similar to the La Manga case $[7,8]$. Many scientists, NGOs and people in general, protested against the project and, in addition, requested protection for natural spaces and historical agricultural land. Maybe this movement was the first ecological movement in Spain.

In 1978, the actual democratic constitution in Spain was approved. The Albufera Lake and El Saler coastal zone were protected. Urban development in these zones was stopped, but not in agricultural land.

In 1978, the new democratic constitution was approved. According to it, legislative powers in urban and regional passed to the new regional governments. In 1988, a new metropolitan plan, the Normas de Coordinación Metropolitana del Area Metropolitana de Valencia (Coordination Metropolitan Rules for Metropolitan Area of Valencia) was approved. This was a new metropolitan plan to establish land reservation for: infrastructures (especially transport), regional public facilities and protected areas. According to this plan, an important part of agricultural land was protected but not everything. These metropolitan rules were implemented by Consell Metropolità de L'Horta (L'Horta Metropolitan Council).

In 1999, the Metropolitan Council was removed due to a conflict of interest between the metropolitan organization and municipalities.

Municipalities wanted to be free to promote urban development in its municipal boundaries during the time of the 1997-2007 housing boom. At the same time, in 2000-2001, a new popular movement promoted an act, by system of "popular 
legislative initiative" for protecting historical agricultural land [9]. The initiative collected around 118,000 signatures, $10 \%$ of the electoral roll in the area. The Act was rejected by regional parliament, but a new metropolitan plan to protect agricultural land was initiated after many years [10].

In figure 4 you can see agricultural land (green), urban zones (red) and other uses (white) in Valencia in 2000 with boundary of new plan and boundary of $L$ 'Horta region. The initial strategy, in 2007, to intervene in agricultural land was based on the popular Act proposal [11]:

- Regional planning: Territorial Action Plan for protection of L'Horta de Valencia

- Socioeconomic agricultural plans and rural tourist plan

- Horta Act and creation of a Management Entity to protected area

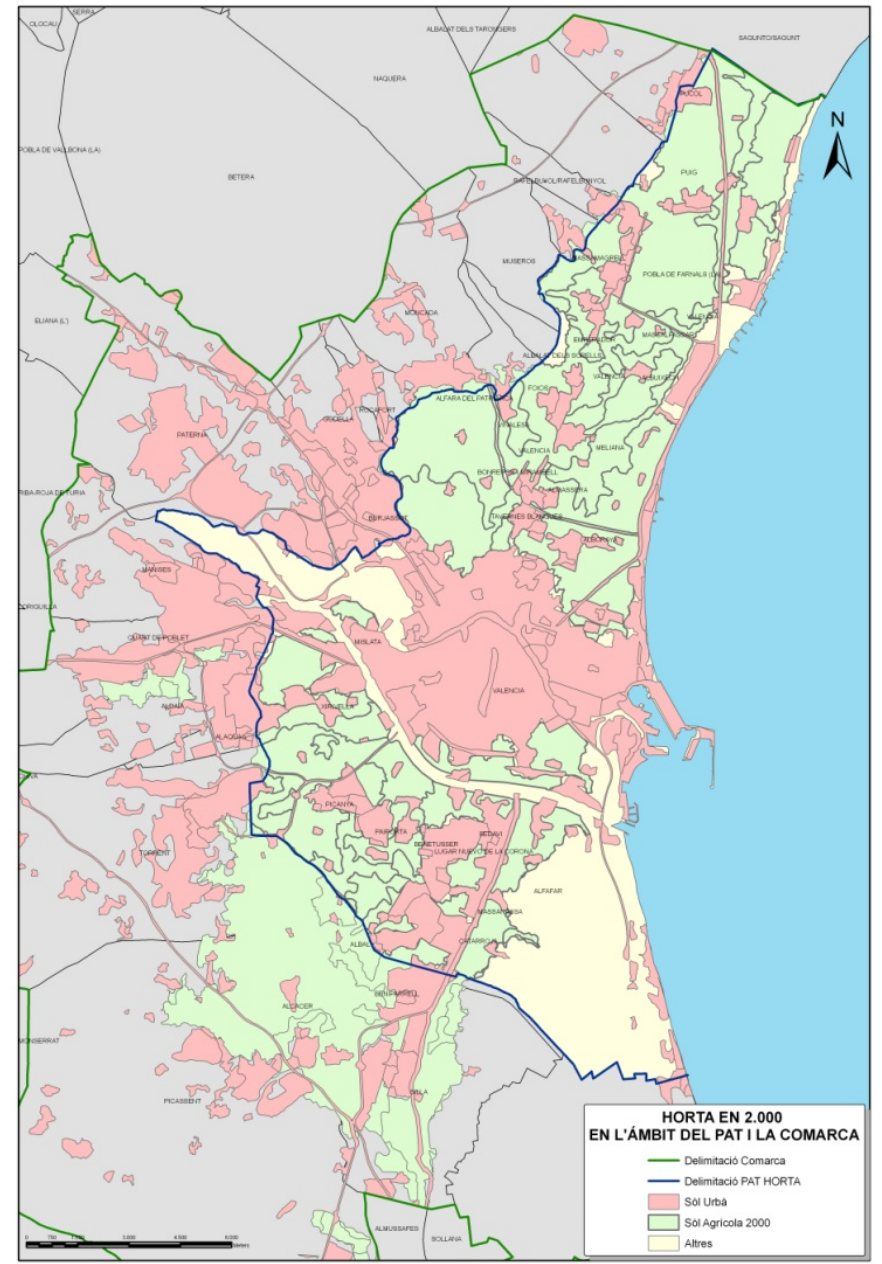

Figure 4: Agricultural land in Valencia in 2000. 
Finally, in 2011, the plan was finalised but not approved. Never started working about complementary instruments: agricultural plan, rural tourist plan, Horta Act and Management Entity.

\section{Causes of continued failure}

Why? Why has it not been possible to conduct intervention projects? Why, despite all the time passed, did any of the instruments of intervention not run?

We can identify three essential unresolved contradictions in our society that you can see in figure 5 .

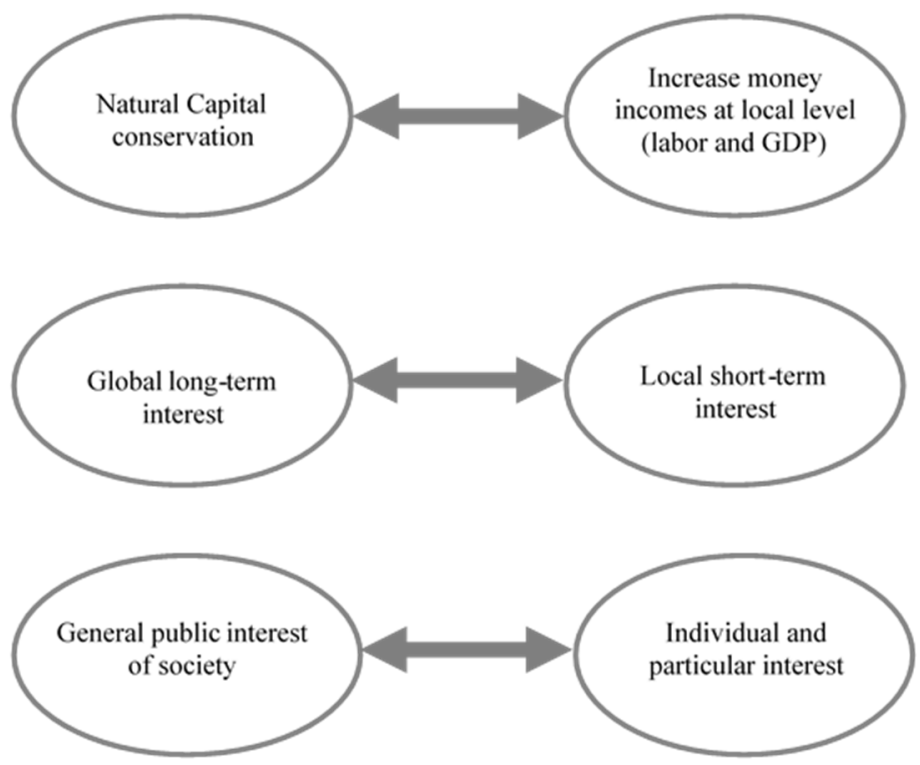

Figure 5: Essential unresolved contradictions.

The causes for the failure of the intervention in agricultural land of L'Horta, which are explained below, are an expression of some of these contradictions.

\subsection{Interest of land owners to increase income by sales of land for building}

In the last period of real estate boom in Spain and Valencia, during 1997-2007, prices of protected agricultural land to change protection and build on, went up to 180 euros per square meter. Therefore, a normal plot of $3,000 \mathrm{~m}^{2}$ could be sold for 540,000 euros. In this situation, in general, the farmer wants to sell their land. The land prices to build on is always much higher than its price for agriculture [12].

Farmers, in general, want to increase their income and don't want protection for their land. They think that if society wants to conserve the natural capital of agricultural land, society must pay for the conservation. Conservation cannot be 
at the expense of the farmers. This question justifies management systems, as an ecological tax to pay for the conservation by land stewardship contracts, for example.

However the high price of land was produced by a speculative process. In fact this is one of the causes that has produced the current economic crisis in Valencia and Spain $[13,14]$. Facts have proved that this high value market price of land to build on produces a tendency to destruct the natural capital. In addition, the land market to build does not generate economic progress but debt, because the market value is only an expectation value. It is necessary to revise the theory of property of land to build.

\subsection{Interest of municipalities to prepare land to build}

Since the 1975 Land Act in Spain, municipalities can obtain significant income from urban development. In the period of real estate boom, 1997-2007, many municipalities promoted urban development to increase income [15]. In addition, local governments often serve request of owners, real estate developers, builders and homebuyers.

The period of government in democracy is short, 4 years in Spain. So local governments prefer to increase income in the short-term, serve local interest in the short-term but particularly interest versus general public interest to conserve natural capital in the long-term.

Therefore, it is necessary to revise governance to guarantee long-term public interest.

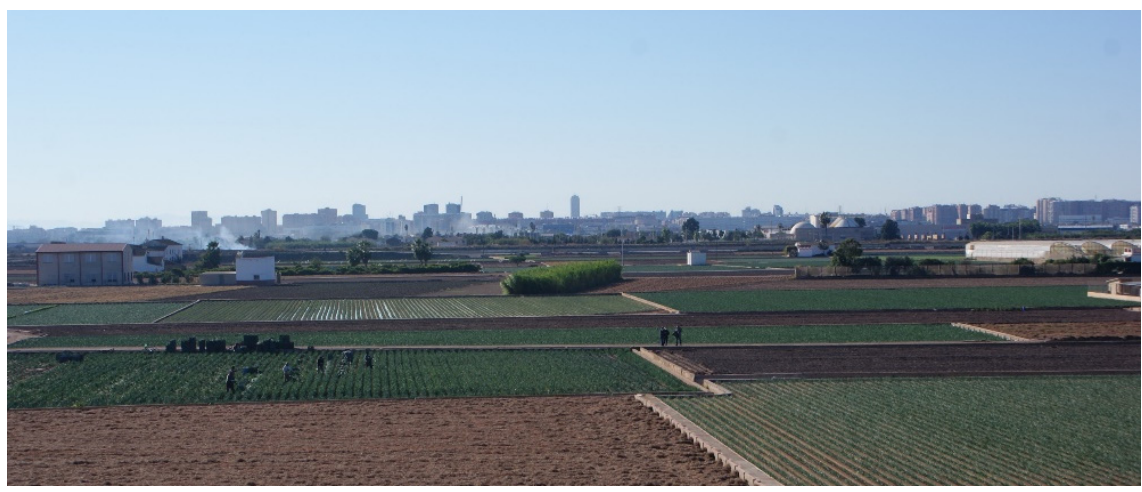

Figure 6: Landscape of L'Horta around Valencia City.

\subsection{Low profitability of crops}

Farmers always say that agricultural prices are very low. However, the agricultural land in Valencia is always in production. It is an extensive land made up of small farms with intensive production. On the other hand, ecological agriculture and landscape conservation implies conditions. For example, it is not compatible with 
the cultivation under plastic. For all these reasons, it is necessary to use new management systems to finance landscape conservation.

This situation is contradictory with the global situation of food speculation [16]. From a strategic standpoint, the Valencian society should preserve and maintain a natural resource that, globally, is increasing in appreciation

On 20 December 2013, the four Basic Regulations and the Transition Rules were published in the Official Journal of European Union [17]. The new Common Agricultural Policy (based with three strategic aims: food security; quality, value and diversity of food; and employment [18]) will help to improve the situation.

\subsection{Inadequate distribution of the costs of sustainability}

If society wants to conserve the landscape in quality conditions as a green infrastructure for citizens [19], society must pay the added costs. Peri-urban space of L'Horta is not only an agricultural historical land, it is also a big open space for the enjoyment of citizens and a good landscape for rural tourism. Accordingly, society and rural tourism activities should help to finance landscape conservation.

\section{Conclusions}

Conventional systems for regional planning and management are ineffective and insufficient to act on the current real situation of historic farmland of Valencia. Conventional systems cannot successfully solve current contradictions in order to guarantee a better future for society.

In fact, peri-urban agricultural spaces of Valencia are a symbol of precious natural and cultural goods. An example of very intense conflict between todays interests over tomorrows interests. A laboratory which tests new instruments to search guaranteed natural resources for the future.

The experience of Valencia suggests a list of structural changes to act successfully in peri-urban spaces of natural resources. Strictly, these structural changes or new social rules must be realized in regional constitution or state constitution. It is only possible to pilot experiences by law only.

\subsection{Revised property theory about the ground to build on}

Current property theory was born in the XVIII century. However, current environmental problems are much more important and current technology is very different. Today the property registration is digital, we can see all the plots of Spain on-line and we can distinguish between the ground and the underground.

On the other hand, we must remember that, as in the XVIII century, the only source of wealth is labor [20]. The work of workers and organized labor in companies. From the work, society produces goods and services to consume. Therefore, we can establish a basic social and economic principle: every worker or company must receive economic compensation for the goods and services it produces. 
Nevertheless, to ensure that this principle is efficient, it must also meet its corollary: no worker or company must pay nothing for goods and services that no one has produced.

In the case of land, we have two goods: the ground and the underground. The ground is the surface of land that is used for agricultural activities. The underground is the geological material under the ground. The ground is improved by farmers. The underground is natural goods that no one has produced. When a building or public work is constructed, the ground is removed to cement in the underground. That is, the owner is really the owner of the land but not the owner of the underground or not the owner of geographic coordinates.

Therefore, land for building must be public and so the speculative land market for building on will be removed. In this situation, land value is according to agricultural use and expected urban uses cannot influence the price of land. Thus, speculative land prices would not be cause for the destruction of natural resources.

\subsection{Revised governance system: administrative organization and environmental power}

Current administrative organization cannot guarantee environmental interest in the long-term. Usually, the protection of natural resources was realized by an act, but all acts can be changed when legislative power changes. In Spain, legislative power chooses executive power for four years. New legislative power can always change protection laws.

It is necessary to have another power, an environmental power, to guarantee environmental interest in the long-term. Remember when the theory of the three powers created at the time of the French Revolution (legislative, executive and judicial), environmental problems were not considered. Therefore, society organized by these three powers do not guarantee public environmental interest and therefore does not guarantee long-term environmental interests.

This new power must be independent of legislative, executive and judicial powers. It should operate under the principle "political protection and technical custody". That is, natural resources protection must be a legislative democratic decision but, once natural resources have been protected, the environmental power will have the custody of those protected resources as a function. In this situation, unprotected natural resources or territory can only be possible by resolution of environmental power. In other words, democratic legislative powers take decisions about protecting resources or areas for the long term, but the responsibility of the management of it corresponds to other institutions. This environmental power must also realize environmental reports for environmental impact process and strategic environmental assessment.

The function of environmental power will be equivalent, in the environmental field, to the role of the European Central Bank in the economic field. If European Central Bank have as a function guaranteed monetary equilibrium or guaranteed assets measured by currency, environmental power must be an institution for guaranteed natural heritage for the long-term. Therefore, we can name this power or institution as a Natural Capital Bank [21]. The Governing Board of this 
institution shall be elected by a system to ensure its independence from the executive and legislative powers.

On the other hand, in Spain we have about 8,000 municipalities. Many of them with very little population. In this current situation, with a very developed transport system, the geographic scope more appropriate to fixed uses is the functional area or metropolitan area, not municipal area. For this reason, we need governance revision. Rethink local administration, functional area for each level of administration and their different competencies for managing public services.

\subsection{Translate to society the cost of sustainability}

The need of sustainability produces a cost for today, for more benefits tomorrow. These costs should be distributed among the beneficiaries of environmental services. If general society is the beneficiary, then she should bear the cost.

Management systems, as ecological tax, can be used to finance land stewardship contracts. The contract can regulate agricultural use conditioned to landscape quality and the commitment to not develop urban in exchange for an annual payment.

However, in the future, if agricultural land will be transformed for building or public works construction, then the contract will not be fulfilled and the developer must return all payments with interest. Of course, this cost must be borne by the urban developer or public world developer. This cost increases the final price of the building or public work. It is a way to pass the cost of sustainability to the product price: building or public work.

\section{References}

[1] TERRASIT. http://www.icv.gva.es/.

[2] Biot Gimeno, C. La agricultura ecológica, alternativa para la preservación de la Huerta de Valencia. Generalitat Valenciana. Conselleria d'Agricultura, Pesca i Alimentació: València, 1998.

[3] Antolín Tomás, C. \& Añó Vidal, C. Capacitat d'ús dels sols de la Comunitat Valenciana. El Sòl com a recurs natural a la Comunitat Valenciana. Generalitat Valenciana. Conselleria d'Obres Públiques, Urbanisme i Transports: València, 1998.

[4] Miralles i Garcia, J.L. Sustainability regulations in urban planning: the experience of the Autonomous Community of Valencia (Spain). WIT Transactions on Ecology and the Environment, Vol 120, WIT Press: Southampton, pp. 3-12, 2009.

[5] Miralles i Garcia, J.L. Los espacios agrícoles en las periferias de las áreas metropolitanes en España. El caso de L'Horta de València. Cooperare atrraverso l'Atlantico. Analisi, strategie e progetti per la riqualificazione dei margini urbani nei paesi latini europei e americani. Laboratorio di Cooperazione Internazionale, Politecnico di Milano: Milano, 2012.

[6] Europe's Environment: Dobris Assessment. European Environment Agency. http://www.eea.europa.eu/publications. 
[7] García-Ayllón, S. En los procesos de urbanización del mediterráneo: el caso La Manga. PhD thesis, Politechnic University of Valencia (Spain), 2013.

[8] Miralles, J.L. \& García-Ayllón, S. The economic sustainability in urban planning: case La Manga. WIT Transactions on Ecology and the Environment, Vol. 173, WIT Press: Southampton, pp. 279-290, 2013.

[9] Miralles i Garcia, J.L. El patrimonio rural periurbano: el caso de L'Horta de Valencia. Ingeniería y Territorio, Vol. 75, Colegio de Ingenieros de Caminos, Canales y Puertos: Barcelona, pp. 78-85, 2006.

[10] Miralles i Garcia, J.L. The Planning of Peri-Urban Agricultural Areas: the Case of L'Horta de Valencia. Proc. of REAL CORP 2013. Planning times, eds Manfred SCHRENK, Vasily POPOVICH, Peter ZEILE \& Pietro ELISEI: Rome, pp. 953-962, 2013.

[11] Muñoz Criado, A. Plan de la Huerta de Valencia. Un paisaje cultural milenario., vol. 1 Estrategias de Preservación y Gestión. Generalitat Valenciana. Conselleria de Medi Ambient, Aigua, Urbanisme i Habitatge: Valencia, 2009.

[12] Courtot, R. La huerta de Valencia ¿Qué porvenir? La Huerta de Valencia. Un paisaje cultural con futuro incierto, ed. J. Romero \& M. Francés, Universitat de València: Valencia, pp. 15-31, 2012.

[13] Miralles i Garcia, J.L. Real estate crisi and sustainability in Spain. WIT Transactions on Ecology and Environment. Vol. 150, WIT Press: Southampton, pp. 123-133, 2011.

[14] Miralles i Garcia, J.L. El darrer cicle immobiliari al País Valencià. O el progrés de la misèria. Fundació Nexe: València, 2014.

[15] García-Ayllón, S. Retrospective analysis of urban development in the Spanish Mediterranean Coast. WIT Transactions on Ecology and the Environment, Vol. 179, WIT Press, pp. 291-302, 2013.

[16] Food Speculation; Global Agriculture. http://www.globalagriculture.org/ report-topics/food-speculation.html.

[17] European Commission, http:/ec.europa.eu/agriculture/cap-post-2013/.

[18] The CAP towards 2020: Meeting the food, natural resources and territorial challenges of the future. European Commission, http://ec.europa.eu/ agriculture/cap-post-2013/communication/index_en.htm.

[19] Andreucci, M.B. Progressing Green Infrastructure in Europe, WIT Tansactions on Ecology and the Environment, Vol. 179, WIT Press, pp. 413-422, 2013.

[20] Smith, A. The Wealth of Nations. MetaLibri Digital Library. http://www.ibiblio.org/ml/libri/s/SmithA_WealthNations_s.pdf.

[21] Miralles i Garcia, J.L. \&Gaja i Díaz, F. Proposal for to Natural Capital Bank as a managing tool for urban management sustainability, WIT Tansactions on Ecology and the Environment, Vol. 54, WIT Press, pp. 477-486, 2002. 